\title{
MICROBIAL DIVERSITY OF MARINE SPONGES
}

\section{UTE HENTSCHEL}

Zentrum für Infektionsforschung, Röntgenring 11, D 97070 Würzburg, Germany

E-mail: ute.hentschel@mail.uni-wuerzburg.de

\begin{abstract}
16S rDNA library construction revealed a uniform microbial community in sponges that were collected from different oceans. Altogether 14 monophyletic, sponge-specific sequence clusters were identified that belong to at least seven different bacterial divisions. By definition, the sequences of each cluster are more closely related to each other than to a sequence from non-sponge sources. These monophyletic clusters comprise $70 \%$ of all publicly available, sponge-derived $16 \mathrm{~S}$ rDNA sequences reflecting the generality of the observed phenomenon. This shared microbial fraction represents the 'smallest common denominator' of the sponges investigated in this study. Bacteria that are exclusively found in certain host species or that occur only transiently would have been missed. A picture emerges where sponges can be viewed as highly concentrated reservoirs of so far uncultured, elusive and possibly evolutionarily ancient marine microorganisms.
\end{abstract}

\section{KEY WORDS}

Sponge, 16S rDNA library, microbial diversity, monophyletic clusters.

\section{INTRODUCTION}

Sponges (Porifera) form one of the deepest radiations of the metazoa whose origins date back to the Precambrian. Being the oldest still extant animal phylum, they have been confronted with microorganisms for long periods of time. Because of their diploblast organization, true tissues or organs are lacking. Instead they possess single, amoeboid cells (archaeocytes) that move freely through the threedimensional matrix, termed the mesohyl. The omnipotent archaeocytes are responsible for nutrition, excretion and gas exchange and can also be the source of oocytes during sexual reproduction. In spite of their basic organization, sponges are true metazoans that can reach considerable size $(>1 \mathrm{~m})$ particularly in tropical waters. The identification of genes and proteins that are highly homologous to vertebrate analogs provides unequivocal evidence for their affiliation to the higher metazoa (for example, MEHL et al., 1998).

Some sponges have been reported to contain large amounts of microorganisms within their tissues (for a recent reviews, see HENTSCHEL et al., 2003; IMHOFF \& STÖHR, 2003). In Aplysina aerophoba, microorganisms may contribute up to $40 \%$ of the biomass which exceeds the bacterial concentrations of seawater by two- three orders of magnitude (VACELET, 1975; FRIEDRICH et al., 2001). This population consists mostly of extracellular bacteria that are embedded within the mesohyl matrix and that are physically separated from the seawater by host membranes. Because sponge-bacteria interactions are presumably evolutionarily ancient, widely 
distributed, and in some cases specific to their host, it is generally believed that symbiotic interactions exist between sponges and microorganisms. Accordingly, several symbiotic functions have been attributed to the microbes that include nutrient acquisition, processing of metabolic waste, involvement in secondary metabolite production and host defense, and the stabilisation of the sponge skeleton.

With the availability of molecular tools for community analyses in microbial ecology, the area of sponge microbiology has gained new momentum. It is now possible to obtain phylogenetic information on complex microbial consortia, including those that have so far eluded cultivation efforts. The application of molecular ecology tools has revealed that the microbial communities of certain sponges are distinctly different from that of seawater (SCHUMANN-KINDEL et al., 1997; LOPEZ et al., 1999; FRIEDRICH et al., 1999; WEBSTER et al., 2001a; HENTSCHEL et al., 2002; THOMS et al., 2003; TAYLOR et al., 2004) whereas the microbial communities of other sponges reflect more closely the seawater microbial composition (WEBSTER et al., 2004). In this study we have employed 16S rDNA library construction to provide insights into phylogenetic diversity of spongeassociated microbial communities.

\section{MATERIAL AND METHODS}

The construction of $16 \mathrm{~S} \mathrm{rDNA}$ libraries was done in collaboration with B. S. Moore (University of Arizona at Tuscon) and J. Hopke (formerly at the University of Arizona at Tuscon; now at Aventis Pharma, Cambridge MA). The sponge Aplysina aerophoba (Verongida) was collected by SCUBA diving off Banyuls-sur-Mer (France) and the sponge Theonella swinhoei (Lithistida) was collected off the Western Caroline Islands (Republic of Palau), the Red Sea and off Japan. Individual specimens were placed separately into plastic bags and brought to the surface. Tissue samples were removed from the center with a sterilized cork borer and rinsed in autoclaved, artificial seawater. 16S rDNA library construction was performed as described in HENTSCHEL et al. (2002). Briefly, genomic DNA was extracted from liquid nitrogen frozen sponge tissues using the QIAamp tissue kit (Qiagen) and the Fast DNA Spin Kit for soil (Q-Biogene, Heidelberg, Germany). Following PCR amplification with the universal, eubacterial $16 \mathrm{~S}$ rDNA-targeted primers $27 \mathrm{f}+1385 \mathrm{r}(1492 \mathrm{r})$, the resulting product was ligated into a suitable cloning vector and transformed into competent Escherichia coli cells. Sequencing was performed on LICOR and ABI automated sequencers. Phylogenetic analyses and tree construction were performed using the ARB software package (www.arbhome.de).

\section{RESULTS}

160 clone sequences were recovered from the sponges Aplysina aerophoba Schmidt, 1862 and Theonella swinhoei Gray, 1868. Additional sponge-derived 16S rDNA sequences from Halichondria panicea (Pallas, 1766) (Halichondrida) and from Rhopaloeides odorabile Thompson, et al., 1987 (Dictyoceratida) were included in this study for comparison (ALTHOFF et al., 1998; WEBSTER et al., 2001a,b). The majority of all sponge-derived sequences is related to the Acidobacteria division and the Chloroflexi (Fig. 1). Clones affiliated with the Actinobacteria, Alpha-, Gamma-, and the Deltaproteobacteria were also abundant. Sequences related to the Bacteroidetes and the Spirochaetes were only minor components of the gene libraries. The phylogenetic identity of several deeply-branching lineages within the domain Bacteria could not be 
resolved. More than two thirds of all sponge-derived 16S rDNA sequences showed less than $90 \%$ homology to their nearest sequence relatives from non-sponge sources, indicating the occurrence of many, previously not recognized bacteria within these animals. Fluorescence-in-situ-hybridization with 16S rRNA oligonucleotide probes (FISH) directed against sponge-specific sequence clusters confirmed the presence of the respective microorganisms within sponge tissues (data not shown). In $A$. aerophoba, a pronounced dominance of bacteria belonging to the phylum Chloroflexi and one novel, deeply branching lineage was observed. None of the sequences represent culturable isolates.

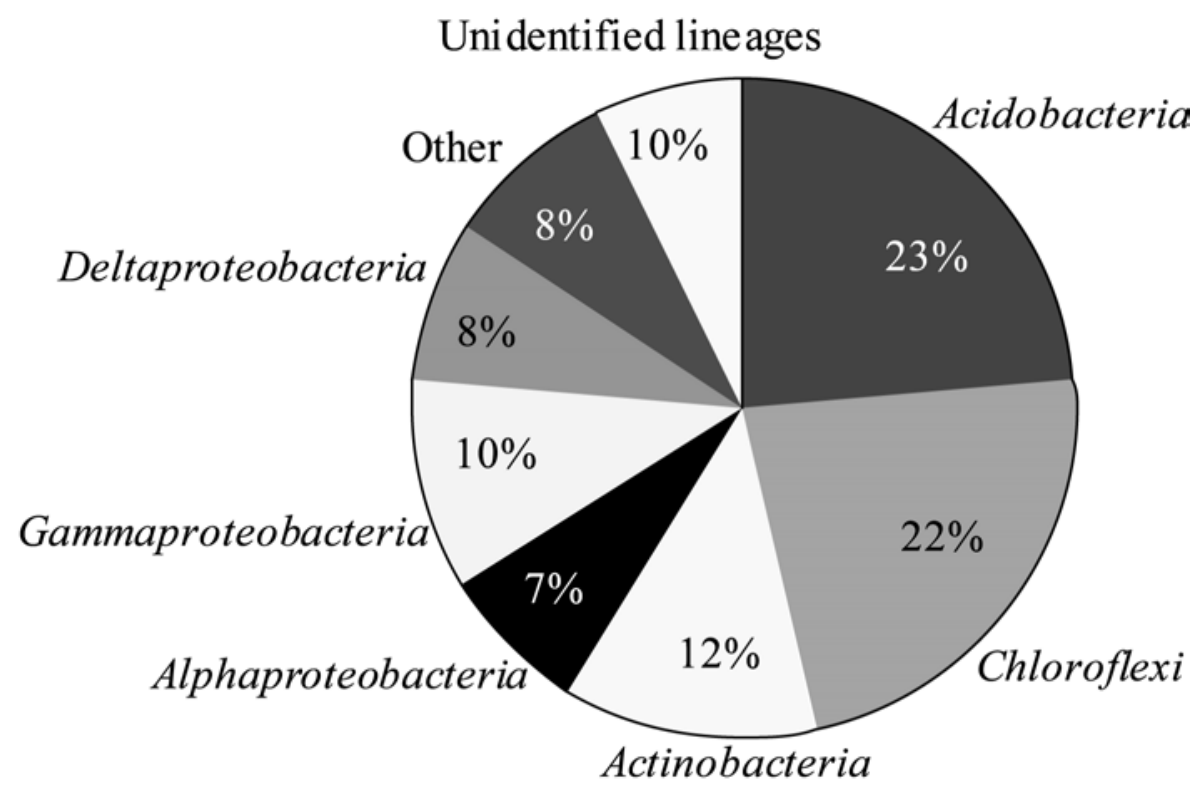

Fig. 1. Microbial community composition of sponges based on $16 \mathrm{~S}$ rDNA sequence analysis.

Interestingly, more than two thirds of all publicly available, sponge-derived sequences fall into distinct clusters. We have defined these 'monophyletic clusters' as groups of at least three sequences that have been recovered from different sponge species and/or from different geographic locations. The sequences of these monophyletic clusters are, by definition, more closely related to each other than to any other environmental sequence. Altogether, 14 monophyletic and 3 polyphyletic clusters were identified, the latter also include environmental sequences. Five monophyletic sequence clusters are present in each of the $16 \mathrm{~S}$ rDNA clone libraries that have been constructed to date (Fig. 2). 


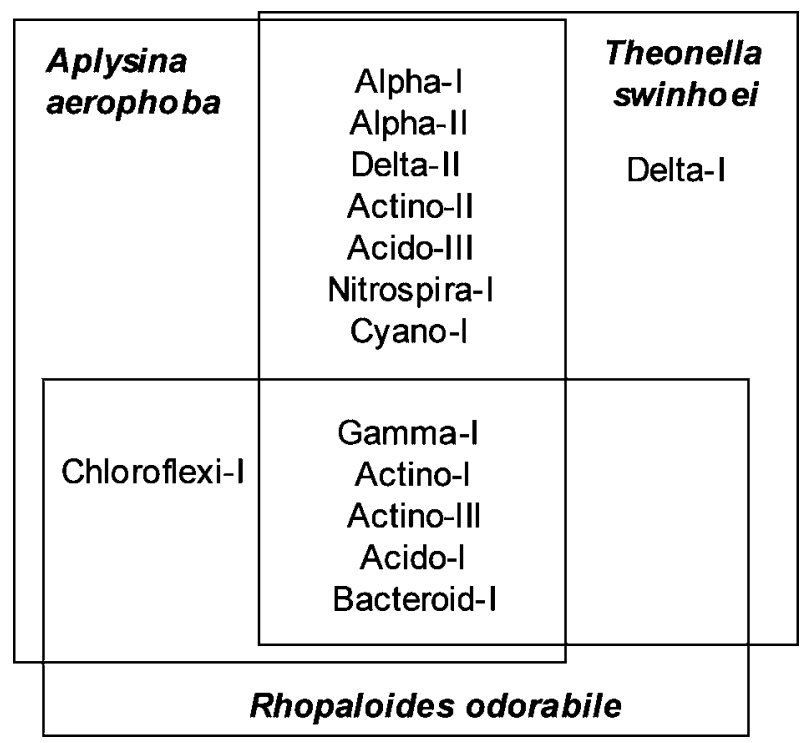

Fig. 2. Monophyletic sequence clusters of three marine sponges.

\section{DISCUSSION AND CONCLUSIONS}

With the comparative $16 \mathrm{~S}$ rDNA approach, a uniform, sponge-specific microbial community was discovered in taxonomically distantly related sponges that were collected from different oceans. With respect to complexity, the microbial consortium of these animals resembles more closely the beneficial assemblages of rumen (TAJIMA et al., 1999), the mammalian gut (PRYDE et al., 1999) and the squid nidamental gland (BARBIERI et al., 2001) than the more intimate symbiotic associations commonly observed with invertebrate hosts (STEINERT et al., 2000). Even though the phylogenetic diversity is complex, the overall extent is limited. This is indicated by the fact that the same sequence phylotypes are found repeatedly in different sponges. Sponges may be regarded as 'microbial fermenters' with a unique and specific microbial signature. The elucidation of the genetic and physiological properties of the microbial communities and their potential symbiotic functions poses challenging future questions.

The mechanisms that have shaped the microbial community structure of sponges are intriguing. So far there is no evidence that the characteristic secondary metabolite profiles of the host have an effect on microbial community composition. Moreover, the geography does not seem to play a major role as the specimens were collected from different oceans. In contrast, sponge morphology might have an influence upon microbial community composition. It is interesting to note that Aplysina 
aerophoba, Rhopaloeides odorabile and Theonella swinhoei share a similiar habitus. These are erect animals with pronounced chimneys and a well-developed mesohyl. It has been recognized for many years that the presence of bacteria is correlated with sponge morphology (VACELET \& DONADEY, 1977; WILKINSON, 1978). Sponges with a high mesohyl density and a poorly developed aquiferous system appear to contain large amounts of bacteria whereas those with a low tissue density and a well developed aquiferous system apparerently contain few bacteria (VACELET \& DONADEY, 1977; WILKINSON, 1978; HeNTSCHEL et al., 2003). Accordingly, the phylogenetic identity of microorganisms might be entirely different in encrusting or rope-shaped sponges or in those that contain naturally only very few bacteria.

Because of the evolutionary age of sponges it is tempting to speculate that they may have coevolved with their bacteria. At least two reports provide experimental evidence for coevolution between sponge hosts and symbiotic bacteria (THACKER \& STARNES, 2003; ERPENBECK et al., 2002). Coevolution generally implies that the bacteria are transferred vertically to the next generation. Sponges are unusual in the animal kingdom in that oocytes may arise from somatic cells, the archaeocytes. Bacteria have indeed been observed in reproductive stages, such as the oocytes and larvae (GALLISSIAN \& VACELET, 1976; LÉVI \& LÉVI, 1976; KAYE, 1991; UsHER et al., 2001; SCISCIOLI et al., 2002). However, it is presently not known whether the bacteria serve as nutrition or whether these are specifically passed on to the next generation. USHER et al. (2001) have shown that about $25 \%$ of the larvae of Chondrilla australiensis contain Cyanobacteria indicating that a certain element of variability is involved. Moreover, many sponges are also capable of asexual reproduction which involves the formation of buds, branches or gemmules that develop into viable adults. Asexual reproductive forms may act as vehicles to transmit bacteria to the next generation. If vertical transmission of symbionts occurs in sponges, it may not be as stringent as has been reported for other invertebratesymbiont associations.

Sponges, being sessile filter-feeders, are capable of pumping large volumes of seawater (up to 24,000 liters of seawater day-1 $\mathrm{kg}^{-1}$ sponge $\mathrm{e}^{-1}$ ) through a specialized aquiferous system (VOGEL, 1977). Microorganisms are removed from the seawater and transported into the mesohyl interior where they are digested by phagocytosis. The filtration capacities of sponges are remarkable as the seawater leaving the exhalant osculum is essentially sterile (REISWIG, 1974; PILE, 1997; TURON et al., 1997; WEHRL, 2001). Sponge-specific microbial communities may form if sponges were able to selectively enrich bacteria from seawater and/or if only a subset of bacteria manages to survive within the mesohyl tissue. As of now, bacterial representatives of the sponge-specific clusters have not been found in the environment. If free-living forms do exist in seawater or marine sediments, they must be wide-spread but occur probably at very low abundances.

Our current understanding of the parameters that have shaped the microbial community structure of sponges is as follows: The host provides a physical environment in which the overall habitus, the extent of the aquiferous system, the size of the choanocyte chambers and the thickness of the mesohyl determine the composition and the extent to which bacteria can accumulate. Microorganisms may be acquired vertically through sexual or asexual reproductive forms. Bacteria may also be selectively enriched following filtration from the surrounding seawater. Both 
processes are not mutually exclusive, in fact, the microbial community of an adult sponge may well be a mixture of vertically transmitted and horizontally acquired microorganisms. In order to survive within the mesohyl, bacteria must be able to resist digestion by sponge archaeocytes. It has been noted several times that mesohyl bacteria contain thickened cell walls, multiple membranes and slime capsules which likely serve as barriers to prevent phagocytosis by sponge archaeocytes (WILKINSON et al., 1984; FUERST et al., 1999; FRIEDRICH et al., 2001). Finally, in our view, the bacterial communities of sponges should be considered commensal rather than symbiotic until a specific symbiotic function has been demonstrated.

\section{ACKNOWLEDGEMENTS}

We gratefully acknowledge B. S. Moore, J. Hopke, M. Horn and M. Wagner for excellent collaborations. Financial support was generously provided by bmb $+\mathrm{f}$ grant 'BiotecMarin' (Förderkennzeichen 03F0345E) and by Sonderforschungsbereich 567 to U.H. This paper is dedicated to D. J. Faulkner (1942- 2002).

\section{REFERENCES}

Althoff K., Schütt C., Steffen R., Batel R., MÜller W.E.G., 1998 - Evidence for a symbiosis between bacteria of the genus Rhodobacter and the marine sponge Halichondria panicea: Harbor also for putatively toxic bacteria? Mar. Biol., 130: 529-536.

Barbieri E., Paster B.J., Hughes D., Zurek L., Moser D.P., Teske A., Sogin M.L., 2001 - Phylogenetic characterization of epibiotic bacteria in the accessory nidamental gland and egg capsules of the squid Loligo pealei (Cephalopoda:Loliginidae) Environ. Microbiol., 3: 151167.

ERPENBECK D., BREEWER A., DER VELDE H.C. VAN, SOEST R.W.M. VAN, 2002 - Unravelling host and symbiont phylogenies of halichondrid sponges (Demospongiae: Porifera) using a mitochondrial marker. Mar. Biol., 141: 377-386.

Friedrich A.B., Fischer I., Proksch P., Hacker J., Hentschel U., 2001 - Temporal variation of the microbial community associated with the Mediterranean sponge Aplysina aerophoba. FEMS Microbiol. Ecol., 38: 105-113.

Friedrich A.B., Merkert H., Fendert T., Hacker J., Proksch P., Hentschel U., 1999 Microbial diversity in the marine sponge Aplysina cavernicola (formerly Verongia cavernicola) analyzed by fluorescence in situ hybridisation (FISH). Mar. Biol., 134: 461-470.

Fuerst J.A., WebB R.I., GARson M.J., HARdy L., Reiswig H.M., 1999 - Membrane-bounded nuclear bodies in a diverse range of microbial symbionts of Great Barrier Reef sponges. Mem. Queensl. Mus., 44: 193-203.

GALLISSIAN M.F., VACELET J., 1976 - Ultrastructure des quelques stades de l'ovogenese de spongiaires du genre Verongia (Dictyoceratida). Ann. Sci. Nat. Zool., 18: 381-404.

Hentschel U., Fieseler L., Wehrl M., Gernert C., Steinert M., Horn M., Hacker J., 2003 - Microbial diversity of marine sponges. In W.E.G. Müller (ed.), Molecular Marine Biology of Sponges, Springer Verlag Heidelberg: 59-88.

Hentschel U., Hopke J., Horn M., Friedrich A.B., Wagner M., Hacker J., Moore B.S., 2002 - Molecular evidence for a uniform microbial community in sponges from different oceans. Appl. Environ. Microbiol., 68: 4431-4440. 
IMHOFF J.F., STÖHR R. 2003 - Sponge-associated bacteria: General overview and special aspects of bacteria associated with Halichondria panicea. In W.E.G. Müller (ed.), Molecular Marine Biology of Sponges. Springer Verlag Heidelberg: 35-56.

KAYE H., 1991 - Sexual reproduction in four Caribbean commerical sponges. II. Oogenesis and transfer of bacterial symbionts. Invertebr. Reprod. Dev., 19: 13-24.

LÉVI C., LÉvi P., 1976 - Embryogenese de Chondrosia reniformis (Nardo), demosponge ovipare, et transmission des bacteries symbiotiques. Ann. Sci. Nat. Zool., 18: 367-380.

Lopez J.V., McCarthy P.J., Janda K.E., Willoughby R., Pomponi, S.A., 1999 - Molecular techniques reveal wide phylogenetic diversity of heterotrophic microbes associated with Discodermia spp. (Porifera: Demospongiae). Mem. Queensl. Mus., 44: 329-342.

MeHl D., MÜLler I., MÜLLER W.E.G., 1998 - Molecular biological and paleontological evidence that Eumetazoa, including Porifera (sponges) are of monophyletic origin. In Y. Watanabe, N. Fusetani (eds), Sponge Sciences Multidisciplinary Perspectives. Springer Verlag, Tokyo: 133-156.

PILE A.J., 1997 - Finding Reiswig's missing carbon: Quantification of sponge feeding using dual-beam flow cytometry. Proc. 8th Internat. Coral Reef Symp., Panamá, 2: 1403-1410.

Pryde S.E., Richardson A.J., STEWART C.S., Flint H.J., 1999 - Molecular analysis of the microbial diversity present in the colonic wall, colonic lumen, and cecal lumen of a pig. Appl. Environ. Microbiol., 65: 5372-5377.

REISWIG H., 1974 - Water transport, respiration and energetics of three tropical marine sponges. J. Exp. Mar. Biol. Ecol., 14: 231-249.

Schumann-Kindel G., Bergbauer M., Manz W., SzewzyK U., Reitner J., 1997 Aerobic and anaerobic microorganisms in modern sponges: a possible relationship to fossilization processes. Facies, 36: 268-272.

Sciscioli M., Lepore E, Mastrodonato M., Scalera Liaci L., Gaino E., 2002 Ultrastructural study of the mature oocyte of Tetbya aurantium (Porifera: Demospongiae). Cah. Biol. Mar., 43: 1-7.

Steinert M., Hentschel, U., HACKer. J., 2000 - Symbiosis and pathogenesis: Evolution of the microbe-host interaction. Naturwissenschaften, 87: 1-11.

Tajima K., Aminov R.I. Nagamine T., Ogata K., Nakamura M., Matsui H., Benno Y., 1999 - Rumen bacterial diversity as determined by sequence analysis of $16 \mathrm{~S}$ rDNA libraries. FEMS Microbiol. Ecol., 29: 159-169.

Taylor M.W., Schupp P.J., Dahlöf I., Kjelleberg S., Steinberg P.D., 2004 - Host specificity in marine sponge-associated bacteria, and potential implications for marine microbial diversity. Environ. Microbiol., 6 (2): 121-130.

THACKER R.W., STARNES S., 2003 - Host specificity of symbiotic cyanobacteria, Oscillatoria spongeliae, in marine sponges, Dysidea spp. Mar. Biol., 142: 643-648.

Thoms C., Horn M., Wagner M., Hentschel U., Proksch P., 2003 - Monitoring microbial diversity and natural products profiles of the sponge Aplysina cavernicola following transplantation. Mar. Biol., 142: 685-692.

Turon X., Galera J., URIZ M.J. - 1997 Clearance rates and aquiferous systems in two sponges with contrasting life-history strategies. J. Exp. Zool., 278: 22-36.

Usher K.M., Kuo J., Fromont J., SutTon D.C., 2001 - Vertical transmission of cyanobacterial symbionts in the marine sponge Chondrilla australiensis (Demospongiae). Hydrobiologia, 461: 15-23. 
VACELET J., 1975 - Étude en microscopie électronique de l'association entre bactéries et spongiaires du genre Verongia (Dictyoceratida). J. Microsc. Biol. Cell., 23: 271- 288.

VACELET J., Donadey C., 1977 - Electron microscope study of the association between some sponges and bacteria. J. Exp. Mar. Biol. Ecol., 30: 301-314.

Vogel S., 1977 - Current-induced flow through living sponges in nature. Proc. Natl. Acad. Sci. USA, 74: 2069-2071.

Webster N.S., Negri A.P., Munro M.H.G., BAtTERshill C.N., 2004 - Diverse microbial communities inhabit Antarctic sponges. Environ. Microbiol., 6 (3): 288-300.

Webster N.S., WebB R.I., RidD M.J., Hill R.T., NeGRi A.P., 2001b - The effects of copper on the microbial community of a coral reef sponge. Environ. Microbiol., 31: 19-31.

Webster N.S., Wilson K.J., Blackall L.L., Hill, R.T., 2001a - Phylogenetic diversity of bacteria associated with the marine sponge Rhopaloeides odorabile. Appl. Environ. Microbiol., 67: 434-444.

WeHrL M., 2001 - Masters thesis, Universität Würzburg, Germany.

WILKINSON C.R., 1978 - Microbial associations in sponges. I. Ecology, Physiology and Microbial populations of coral reef sponges. Mar. Biol., 49: 161-167.

WiLKInson C.R., Garrone G., VACELET J., 1984 - Marine sponges discriminate between food bacteria and bacterial symbionts: electron microscope radioautography and in situ evidence. Proc. R. Soc. London B, 220: 519-528. 